\title{
肺移植の現状
}

\section{Current status of lung transplantation}

\author{
伊達洋至 \\ 岡山大学大学院医歯薬学総合研究科 腫瘍 - 胸部外科学 \\ キーワード: 肺移植, 脳死肺移植, 生体肺移植, ドナー, レシピエント
}

\section{はじめに}

日本の肺移植は，1998年10月の岡山大学での生体肺 移植の成功に始まった 。過去 7 年間あまりに80例の 実施例があり，症例数は少ないながらも少しずつ末期 肺疾患の治療として定着しつつある。

ここでは,世界と日本の肺移植を比較するとともに， 岡山大学の肺移植経験を中心に肺移植の現状を述べた w.

\section{肺移植の歴史と現況}

1983年の Cooper ら ${ }^{2)}$ の成功例に始まった脳死者か らの肺移植は，すでに20,000例もの実施数がある 様々な肺疾患に対して定着した医療となっている。

一方, 脳死問題のために日本の移植医療は, 大きく 出遅れた。日本の肺移植は, 1998年10月に岡山大学で の生体肺移植成功に始まっだ).2000年 3 月には, 待 望の脳死肺移植が, 大阪大学と東北大学で始まっ $た^{4,5)}$.

2006年 7 月現在までに, 日本国内で80例の肺移植が

平成18年 7 月受理

下 700-8558 岡山市鹿田町 2-5-1

電話：086-235-7262 FAX : 086-235-7268

E-mail : hdate@md.okayama-u.ac.jp
4 施設 (岡山大 48 例, 大阪大 13 例, 東北大 11 例, 京都 大 8 例）で実施された（図 1 ，表 1 )。そのうち5 2 例

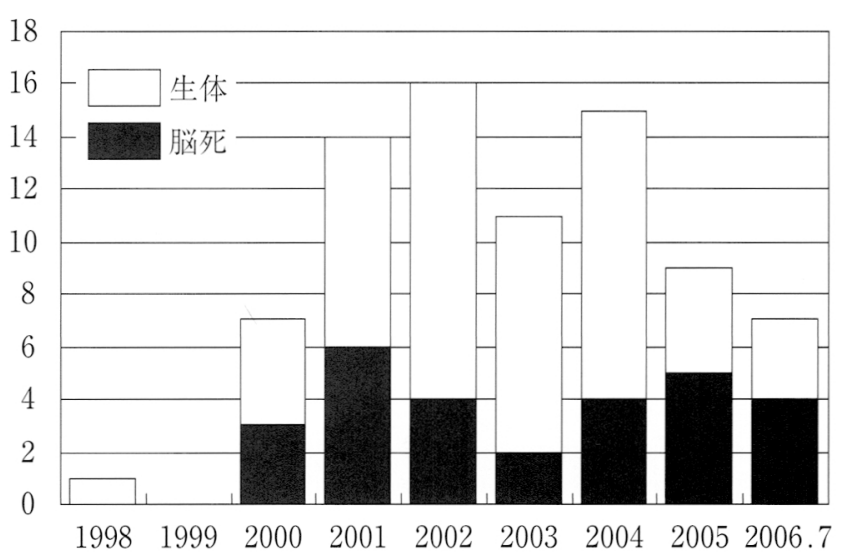

図 1 日本の年度別肺移植施行症例数の推移

日本では, 生体肺移植の方が脳死肺移植よりも多く施行されて いる.

表 1 日本の肺移植施行症例数（2006年 7 月 14 日現在）

\begin{tabular}{cccc}
\hline 施 設 & 脳死肺移植 & 生体肺移植 & 計 \\
\hline 東北大学 & 8 & 3 & 11 \\
京都大学 & 5 & 3 & 8 \\
大阪大学 & 6 & 7 & 13 \\
岡山大学 & 9 & 39 & 48 \\
\hline 計 & 28 & 52 & 80 \\
\hline
\end{tabular}

私は, 1984年に岡山大学医学部を卒業し, 第 2 外科（現在の腫瘍・胸部外科）教室に入局するとともに大学院に すすみました，そして，研究テーマとして肺移植を選択しました．大学院を卒業後，世界で初めて肺移植に成功 した Joel D Cooper 教授の指導を受ける機会に恵まれ，肺移植のすばらしさに魅了されました．1998年10月に 清水信義名誉教授の指導の下, 日本で初めての生体肺移植を執刀することができたのは, 岡山大学附属病院をあ げた協力体制があったからです。

これまでに約2,000例の手術を経験し，呼吸器外科の難しさと奥深さを実感しています，2006年 4 月から腫瘍・ 胸部外科学教室をおあずかりすることになりました，世界に発信できるような仕事を若い先生たちと協力して 行っていきたいものです.
} 
(65\%) が生体肺移植であり，脳死肺移植は28例（35 \%)である.脳死ドナー不足が深刻な日本においては, 脳死肺移植に比べて生体肺移植が主流となっている.

\section{肺移植の適応疾患とその成績}

日本では, 原発性肺高血圧症, 特発性肺線維症, 肺 リンパ脈管筋腫症, 閉塞性細気管支炎, 気管支拡張症 （びまん性沉細気管支炎を含む）などが，適応疾患と して多い(表 2). 欧米で多い肺気腫や囊胞性肺線維症 は，極めて稀である。

国際心肺移植学会の報告では, 肺移植後の 5 年生存 率は $47 \%$ である ${ }^{3)}$ 。心臟や肝臓などの臓器移植後の 5 年生存率が70\%にも達しているのに対して, 肺移植後 の予後は悪いことが知られている，その理由は，移植 後も外界と直接交通しているために感染症の頻度が高 いこと，慢性拒絶反応に対する有効な治療法がないこ

表 2 日本の適応疾患別肺移植施行例（2006年 7 月14日現在）

\begin{tabular}{|c|c|c|c|}
\hline 疾 患 名 & 脳死肺移植 & 生体肺移植 & 計 \\
\hline 原発性肺高血圧症 & 8 & 17 & 25 \\
\hline 特発性間質性肺炎 & 3 & 14 & 17 \\
\hline 肺リンパ脈管筋腫症 & 9 & 4 & 13 \\
\hline 閉塞性細気管支炎 & 2 & 9 & 11 \\
\hline 気管支拡張症 & 2 & 5 & 7 \\
\hline 肺気腫 & 2 & 0 & 2 \\
\hline 間質性肺炎 & 1 & 0 & 1 \\
\hline アイゼンメンジャー & 1 & 1 & 2 \\
\hline 囊胞性肺線維症 & 0 & 1 & 1 \\
\hline 肺囊胞症 & 0 & 1 & 1 \\
\hline 計 & 28 & 52 & 80 \\
\hline
\end{tabular}

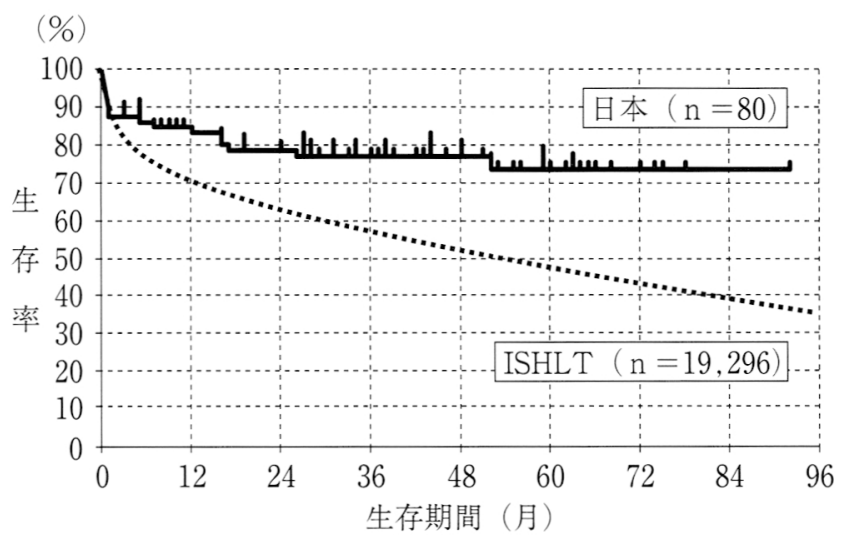

図 2 肺移植後の生存率 (日本 vs ISHLT)

日本の肺移植の 5 年生存率は $74 \%$ であり, 国際心肺移植学会 (ISHLT) の報告 $47 \%$ を大きく上回っている.
とによる，一方，日本で肺移植を受けた患者 80 例中 62 例が生存中であり，その 5 年生存率は $74 \%$ である（図 2 ). 症例数は少なくても, 日本の移植医療の水準の高 さを示している.

\section{脳死肺移植と生体肺移植}

生体肺移植は，二人の健康なドナーがそれぞれの右 あるいは左下葉を提供し，これらをレシピエントの両 肺として移植する方法である(図 3 ). 脳死肺移植と比 べると, 生体肺移植の利点は, 比較的待機手術として 行いうること, 肺の虚血時間が短いこと, 近親者から の臟器提供は拒絶反応が少ない可能性があること, 脳 死ドナーにしばしば見られるような誤燕・感染・人工 呼吸器による肺損傷がないこと，などである。

一方で最大の欠点は健常ドナー 2 人の肺葉切除が必 要であることである，肺は肝臓と違って再生しないた めドナーの肺機能は17〜 18\%程度生涯にわたって低下 する。この程度の肺機能低下は日常生活を行う上で問 題となることはなく，肺葉を提供したドナーに手術関 連死亡は報告されていない。しかし，ドナーには，気 管支癭，出血，気管支狭窄，心膜炎などの合併症が報 告されて抢り ${ }^{6)}$ ，十分なインフォームド・コンセント を行うとともに慎重な適応決定が望まれる。

日本の生体肺移植（52例）と脳死肺移植（28例）の 生存率を図 4 に示した。有意差はないものの, 生体肺 移植の方が生存率では良好な傾向がある。

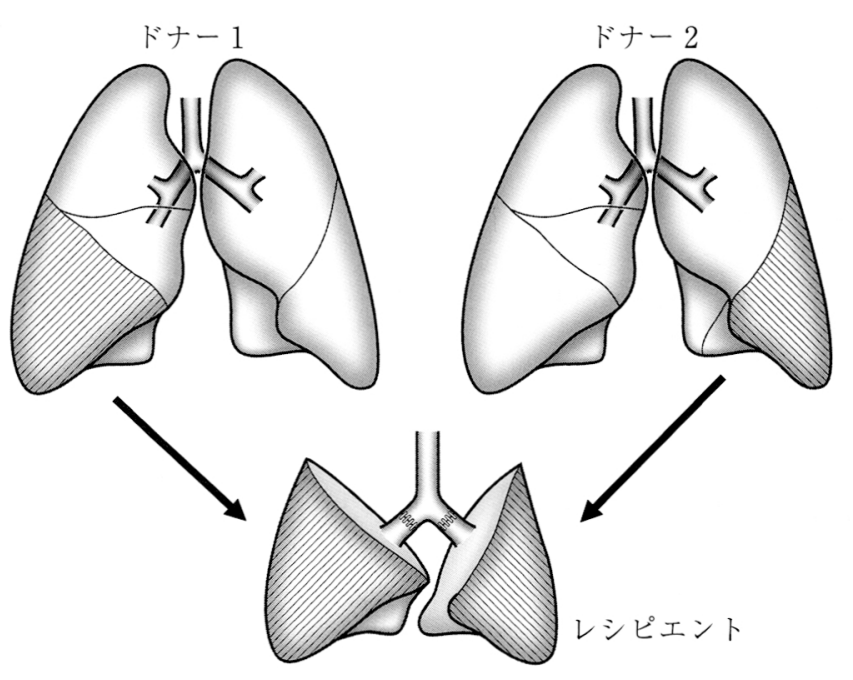

図 3 生体肺移植

健康なドナー二人が右あるいは左下葉を提供し, レシピエント の両肺として移植する。 


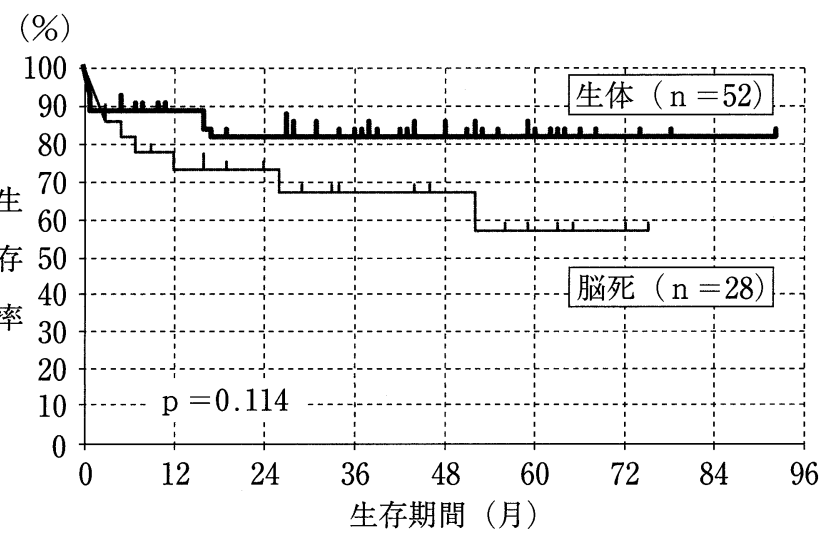

図 4 日本の肺移植後生存率（生体 vs 脳死）

5 年生存率は, 生体肺移植 $82 \%$, 脳死肺移植 $58 \%$ である. $\mathrm{p}=$ 0.114

\section{日本の患者の選択枝}

現在日本には, 肺移植認定施設が 8 施設 (東北大学, 独協大学, 千葉大学, 京都大学, 大阪大学, 岡山大学, 福岡大学, 長崎大学) ある. 脳死肺移植を希望する患 者は，まず，上記の認定施設で, 肺移植の適応の有無 を判定してもらう.さらに, 中央肺移植適応検討委員 会での審査の後, 日本臓器移植ネットワークに登録し て, 脳死ドナーの出現を待つことになる. 日本臓器移 植ネットワークに待機登録している肺移植適応患者は 年々増加し, 120 名を超えた。一方, 過去 6 年間で実施 された脳死肺移植は 28 例にとどまり, 平均待機期間は 約 3 年もある. したがって, 生体肺移植に頼らざる得 ない現状があり, 生体ドナーがいない適応患者の多く が待機中になくなっているという厳しい現実がある.

一方, 生体肺移植に関しては, 各施設での適応判定 だけで施行可能である。健常なドナー二人にメスを入 れるという生体肺移植は決して安易に行われるべきも のでないが, 現実に重症呼吸器疾患患者を救命し, 社 会復帰させることのできる医療であることも証明され た.脳死ドナー数が極めて限られた日本の現状におい ては, 当面の間, 生体肺移植の必要性が高いであろう。

\section{岡山大学の肺移植}

岡山大学では,これまでに48例の肺移植を施行した。 このうち脳死肺移植は 9 例であり, 残り 39 例が生体肺 移植7,8) である。

脳死肺移植 9 例は, 女性 6 例, 男性 3 例で, 両肺移 植が 5 例, 片肺移植が 4 例であった。疾患別では原発
性肺高血圧症 3 例, 肺リンパ脈管筋腫症 3 例, 慢性関 節リウマチに合併した間質性肺炎・閉塞性細気管支 炎・アイゼンメンジャー症候群が各々 1 例であった。 待機日数は22日から1,890日, 平均1,062日であった。 原発性肺高血圧症の 1 例が移植肺機能不全で, アイゼ ンメンジャー症候群の 1 例が出血と移植肺機能不全で 術後早期に死亡した。その他の 7 例は, 社会復帰した。 1 例が慢性拒絶反応のために, 移植後 4 年 4 ケ月で死 亡した。

一方, 生体肺移植の 39 例の対象疾患は, 肺高血圧疾 患 (原発性肺高血圧症 ${ }^{9}$ 10) 12 例, アイゼンメンジャー症 候群 1 例), 閉塞性疾患 (閉塞性細気管支炎 7 例, 肺リ ンパ脈管筋腫症 3 例), 拘束性疾患 (特発性間質性肺 炎 ${ }^{11)} 11$ 例), 感染性疾患 (気管支拡張症 4 例, 囊胞性肺 線維症 1 例）とさまざまな疾患が対象になった。閉塞 性細気管支炎 7 例の原因は, 骨髄移植にともなう GVHD 5 例, アマメシバ摂取 1 例, Stevens-Johnson 症候群 ${ }^{12)} 1$ 例であった。

レシピエントの年齢は 6 歳から 55 歳 (平均 31.1 歳), 8 例が小児患者であった. 男性は 8 例にとどまり, 女 性31例と多かった。特に, 成人男性はわずか 3 名であ った．全員が24時間の酸素吸入を必要としていた，原 発性肺高血圧症は全例プロスタサイクリンの持続静注 療法（平均 $89.0 \mathrm{ng} / \mathrm{kg} / \mathrm{min}$ ) を受けていた。術前状態 は極めて悪く, 26 名 $(67 \%)$ は歩行不能で, 5 名は人 工呼吸器（2 週間から 7 週間）管理下にあった。両側 生体肺移植が37例で, 2 例（10歳男児原発性肺高血圧 症と 6 歳女児閉塞性細気管支炎) は, 母親以外にドナ 一がいなかったため, 右下葉移植を受けた。

ドナー（ $\mathrm{n}=76 ）$ は，いずれも 2 親等以内の血族あ るいは配偶者であった。兄弟 17 名, 母15名, 父11名,

表 3 岡山大学の適応疾患別肺移植施行例 (2006年 7 月14日現在)

\begin{tabular}{lccc}
\hline \multicolumn{1}{c}{ 疾 患 名 } & 脳死肺移植 & 生体肺移植 & 計 \\
\hline 原発性肺高血圧症 & 3 & 12 & 15 \\
特発性間質性肺炎 & 0 & 11 & 11 \\
閉塞性細気管支炎 & 1 & 7 & 8 \\
肺リンバ脈管筋腫症 & 3 & 3 & 6 \\
気管支拡張症 & 0 & 4 & 4 \\
アイゼンメンジャー & 1 & 1 & 2 \\
間質性肺炎 & 1 & 0 & 1 \\
䡒胞性肺線維症 & 0 & 1 & 1 \\
\hline \multicolumn{1}{c}{ 計 } & 9 & 39 & 48 \\
\hline
\end{tabular}




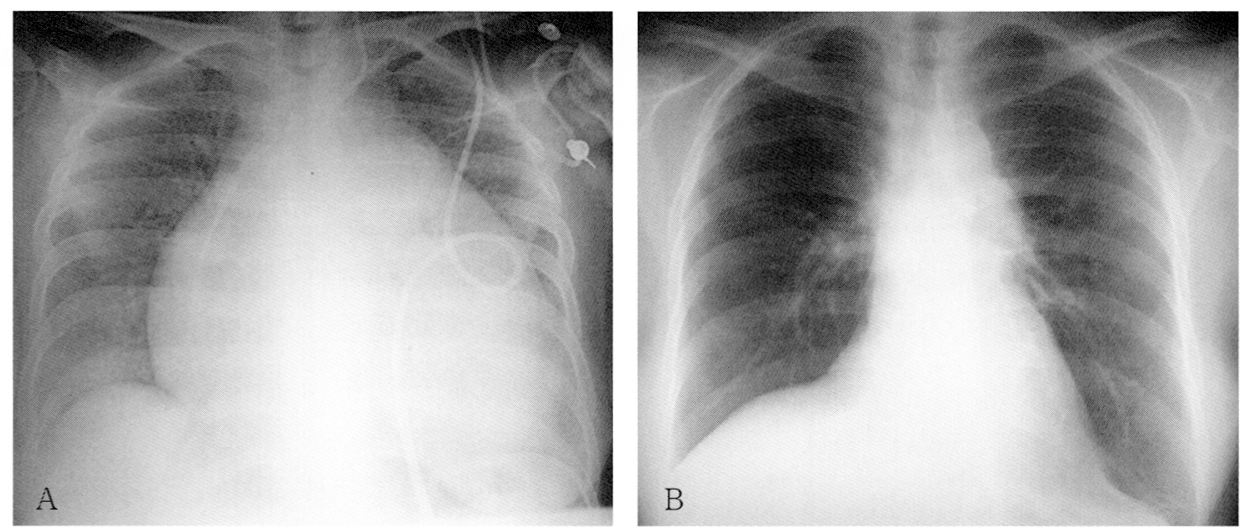

図 52 歳女性, 原発性肺高血圧症

A. 生体肺移植前 B. 生体肺移植㖟

生体肺移植によって心拡大は著明に改善した。

姉妹 12 名, 夫 8 名, 息子 7 名, 娘 5 名, 妻 1 名であっ た。

移植手術後, 全例が手術室で人工心肺から離脱した。 離脱直後の収縮期肺動脈圧は $36.9 \pm 1.7 \mathrm{mmHg}$ であっ た。右肺虚血時間は $158 \pm 7$ 分, 左肺虚血時間は $115 \pm$ 6 分であった。

術後人工呼吸器試用期間は $15.4 \pm 2.8$ 日, 集中治療部 滞在期間は $23.5 \pm 2.9$ 日, 在院日数は $64.7 \pm 4.2$ 日であ つた。

術後合併症は高頻度に起こった。その中には生体肺 移植特有のものも経験した。著明な肺水腫を 6 例に認 めた。虚血時間が短いことから，移植肺が小さいため に肺水腫の頻度が高かったものと思われる。特にこの うち 4 例は, 原発性肺高血圧症患者であり, 人工呼吸 器から離脱してまもなく肺水腫を起こしていることか ら, 本疾患に対する生体肺移植の術後管理上最も注意 すべきことであると思われた。また，生体肺移植後15 日目に原因不明の肺実質から出血（喀血）をきたし， ECMO で救命した症例も経験した。比較的小さな移植 肺に正常な心拍出量が流れ迄んだのも喀血の原因だっ たのかも知れない. 血液型マイナーミスマッチで移植 した症例では，一時的な溶血性貧血が生じた。明らか な感染症は，アスペルギルスの一例のみであった。

呼吸機能は，努力性肺活量，一秒量とも漸増した。 1 年後には予測值の約70\%に達した。これに伴って， 耐運動能も徐々に回復した。移植前はほとんどの患者 が歩行不能であったが, 6 分間歩行距離は 1 年後に 445 $\mathrm{m} に$ 達した。胸部レントゲンも著明に改善した（図 $5)$.
急性拒絶反応とアスペルギルス感染症で死亡した 2 例を除いて，37例 (95\%) が2006年 7 月現在生存中で ある。観察期間は 1 ケ月から93ヶ月であった. QOLも 良好であり, 大半の症例は完全に社会復帰し, 就学. 就業・軽いスポーツなどが可能となった。慢性拒絶反 応は 8 例 $(21 \%)$ に認めたが，いずれも片側にとどま っている. また，9ケ月以内に一秒量の低下は停止し た. 岡山大学においては, 生体肺移植後の予後の方が, 脳死肺移植後の予後よりも有意に良好であった（図 6 ).

ドナー76例の内， 2 例は術後出血のために再開胸止 血術を要した。しかしながら，輸血を必要とした症例 はなかった。また, 膿胸, 乳糜胸のために退院まで約 1 ケ月を要した症例を一例ずつ経験した。最終的に, ドナー全員が術前と同じ生活に復帰した。

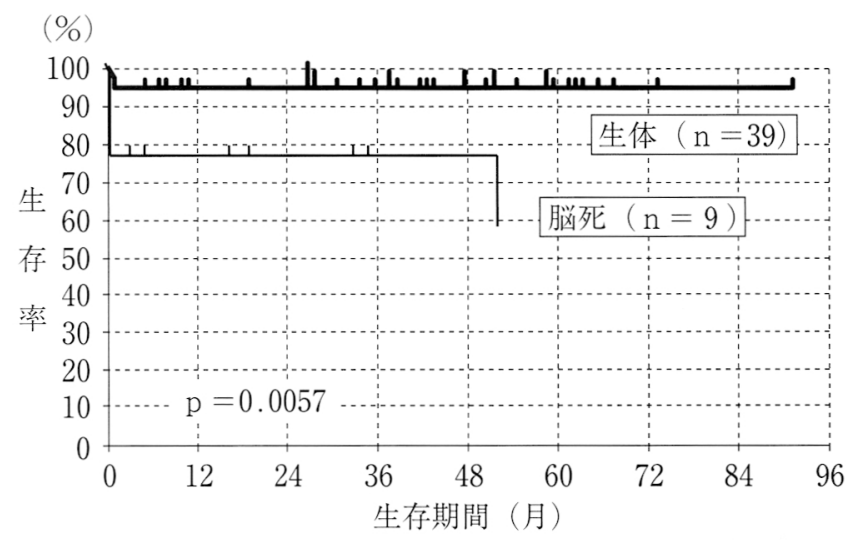

図 6 岡山大学の肺移植適応患者の予後 生体肺移植の 5 年生存率は $94.9 \%$, 脳死肺移植の 4 年生存率は $77.8 \%$ であった. $\mathrm{p}=0.0057$ 


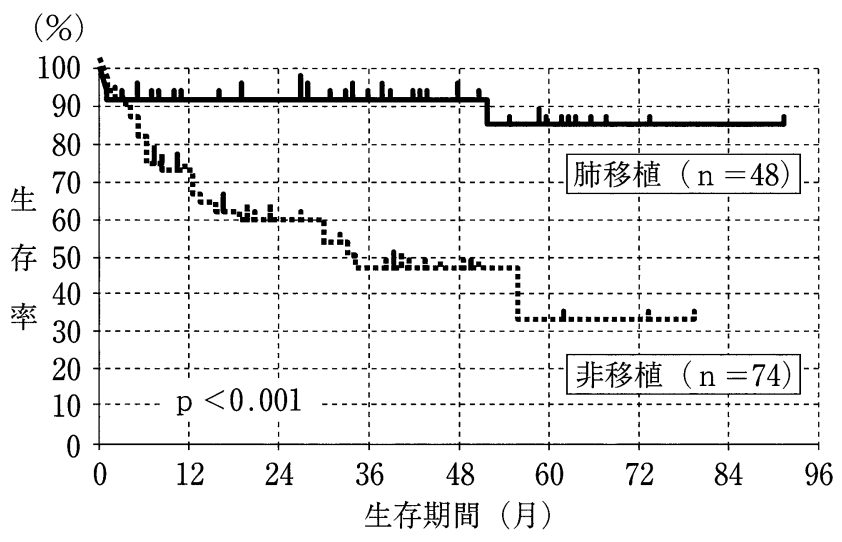

図 7 岡山大学の肺移植適応患者の予後

肺移植後の患者の 5 年生存率は $85.1 \%$ あるるのに対して, 肺移 植を受けなかった患者の平均余命は 2 年半であった. $\mathrm{p}<0.001$

岡山大学では, これまでに 122 名の患者を肺移植の適 応としてきた。そして, 脳死肺移植適応患者のうち, 病気の進行が早く, 脳死ドナーの出現を待つことので きない重症患者を生体肺移植の適応としてきた。その 結果, 122 名中, 9 名が脳死肺移植を受け, 39名が生体 肺移植を受けた。肺移植を受けた48名の生存率は, 肺 移植を受けることのできなかった74名よりも，有意に 良好であった（図 7 ).

\section{将来展望}

日本の肺移植は, 数が少ないものの成績は良好で, 生体肺移植の比重が高いことが示された. 一方で脳死 肺移植の待機中に死亡する患者が後を絶たない現実が ある、極端な脳死ドナー不足を考えると, 臓器移植に 関する法律の改正が強く望まれる。

\section{文献}

1) Date H, Yamashita M, Nagahiro I, et al. : Living-donor lobar lung transplantation for primary ciliary dyskinesia. Ann Thorac Surg (2001) 71, 2008-2009.
2 ) Toronto Lung Transplant Group : Unilateral lung transplantation for pulmonary fibrosis. $N$ Engl J Med (1986) 314, 1140-1145.

3 ) Trulock EP, Edwards LB, Taylor DO, et al. : Registry of the International Society for Heart and Lung Transplantation: Twenty-second official adult lung and heart-lung transplant report-2005. J Heart Lung Transplant (2005) 24, 956-967.

4) Miyoshi S, Minami M, Ohta M, et al. : Single lung transplantation from a brain-dead donor for a patient with idiopathic pulmonary fibrosis. A breakthrough after new legislation in Japan. JJTCV (2001) 49, 398-403.

5 ）松村輔二, 岡田克典, 佐渡 哲, 他：本邦初の脳死肺移植 一右片肺移植一. 今日の移植 (2000) 13，418-425.

6 ) Battafarano RJ, Anderson RC, Meyers BF, Guthrie TJ, Schuller D, Cooper JD, et al. : Perioperative complications after living donor lobectomy. J Thorac Cardiovasc Surg (2000) 120, 909-915.

7 ) Date H, Aoe M, Nagahiro I, et al. : Living-donor lobar lung transplantation for various lung diseases. J Thorac Cardiovasc Surg (2003) 126, 476-481.

8 ) Date H, Aoe M, Y Sano, et al. : Improved survival after living-donor lobar lung transplantation. J Thorac Cardiovasc Surg (2004) 128, 933-940.

9 ) Date H, Nagahiro I, Aoe M, et al. : Living-donor lobar lung transplantation for primary pulmonary hypertension in an adult. J Thorac Cardiovasc Surg (2001) 122, 817-818.

10) Date $H$, Sano $Y$, Aoe $M$, et al. : Living-donor single lobe lung transplantation for primary pulmonary hypertension in a child. J Thorac Cardiovasc Surg (2002) 123, 12111213.

11) Date H, Tanimoto $Y$, Yamadori I, et al. : A new treatment strategy for advanced idiopathic interstitial pneumonia: living-donor lobar lung transplantation. Chest (2005) 128, $1364-1370$.

12) Date $H$, Sano $Y$, Aoe M, et al. : Living-donor lobar lung transplantation for bronchiolitis obliterans after StevensJohnson syndrome. J Thorac Cardiovasc Surg (2002) 123, 389-391. 